\title{
FUNKCIONĀLĀ STRUKTURĀLISMA IDEJAS INTAS FREIMANES PËTİJUMOS
}

Habilitētā filologíijas doktore Latvijas Universitātes emeritētā profesore Inta Freimane ir aktīvi darbojusies latviešu valodniecībā vairāk nekā pusgadsimtu, un viņas intereses saistīiās ar dažādām valodniecības nozarēm, tomēr vērtīgākais devums ir atstāts sintaksē, semantikā un valodas kultūrā, jo šajās nozarēs var runāt par jaunu pētniecisko virzienu un metodolog̣ijas izstrādi.

I. Freimanes darbības sākumposms valodniecības jomā sakrita ar laiku, kad Austrumeiropas valodniecībā izplatìjās strukturālisma idejas, kas citviet pasaulē jau bija guvušas zināmu rezonansi. N̦emot vērā tajā laikā valdošo ideolog̣iju, Austrumeiropas regீionā popularitāti guva Prāgas strukturālisms, kas valodniecības vēsturē pazīstams arī kā funkcionālais strukturālisms. Šì strukturālisma skola izveidojās 20. gs. 20.-30. gados un vairāku gadu desmitu laikā bija radījusi spēcīgu teorētisko bāzi, ko varēja izmantot dažādu valodniecības nozaru pārstāvji. Prāgas strukturālisti piedāvāja strukturālu un funkcionālu pieeju filolog̣ijas zinātṇu pētniecībā, akcentējot gan sistēmas, gan tās elementu funkcionālo aspektu.

Latviešu valodniecībā strukturālistu idejas sāka izmantot un attīstìt profesors Arturs Ozols 20. gs. vidū, un tālāk to turpināja vairāki viņa skolnieki, ieskaitot arī I. Freimani. Savas dzīves laikā profesore ir publicējusi vairāk nekā 70 dažāda apjoma zinātniskos darbus par atšksirīgiem valodniecības jautājumiem, un tajos visos ir vērojama saistîba ar strukturālisma, īpaši Prāgas funkcionālā strukturālisma, teorijām. Vislabāk tas ir vērojams I. Freimanes izstrādātajās monogrāfijās. Pirmais publicētais monogrāfiskais darbs „Latviešu valodas skaņu verbi“ (1983) tika gatavots kā mācību līdzeklis studentiem, kuri apguva speciālkursu „Skaņu verbi latviešu valodas sistēmā“. Tas bija tajā laikā novatorisks pētījums latviešu semantikā, jo pirmo reizi tika aprakstìta konkrēta verbu leksiski semantiskā grupa, kā arī piedāvāta zinātniski pamatota verbu semantiskās analīzes un klasifikācijas sistēma. Darbs bija koncentrēts, un tajā jau skaidri iezīmējās I. Freimanes strukturāā pieeja. Šai monogrāfijai sekoja darbs „Latviešu valodas skaņu verbi: Distributīvs raksturojums“ (1984), kurā I. Freimane iestrādāja skaņu verbu distributīvu leksikogrāfisko modeli. Nākamā I. Freimanes monogrāfija „Vienkāršs teikums un tā paplašināšana“ (1985) tika publicēta pēc gada, un, kaut gan arī šis darbs tika gatavots kā mācìbu līdzeklis studentiem, tomēr vienlaikus tas lielā mērā apliecināja I. Freimanes strukturālo koncepciju sintakses jautājumu izpētē, jo bija vērsts uz jaunas pieejas izmantošanu sintakses nozarē, nevis vienkāršotu teorētiskās bāzes skaidrojumu studentu zināšanu uzlabošanai. No vienas puses, darbā izmantots strukturālismam raksturīgs shematisks valodas apraksta veids - teikums analizēts kā abstrahētas struktūras shēmas izpausme, bet, no otras puses, pirmo reizi analizēts un plašāk aprakstīts arī teikuma dinamiskais jeb komunikatīvais aspekts, tātad 
izcelts tieši funkcionālais aspekts valodas vienību realizācijā. Pēc vairākiem gadiem tika publicēta apjomīgākā I. Freimanes monogrāfija „Valodas kultūra teorētiskā skatīijumā" (1993), kurā autore piedāvāja novatorisku skatījumu uz valodas prakses jautājumiem, pēc Prāgas funkcionālā strukturālisma teorētisko atziņu parauga izstrādājot koncepciju par valodas kultūru kā patstāvīgu zinātnes nozari. Arī šis pētījums tika gatavots kā mācību līdzeklis specialitātes studentiem, tomēr laika gaitā tas kḷuva par nozīmīgu stūrakmeni latviešu normatīvās, resp., preskriptīivās, valodniecības attīstībā. Pēdējā I. Freimanes monogrāfija „Trešā persona latviešu verbu sistēmā““ (2008) ir orig̣ināls pētījums, kurā apvienoti semantikas un gramatikas jautājumi, un arī šoreiz autore paliek uzticīga funkcionālā strukturālisma teorētiskajai bāzei.

Lai ieskicētu dažas nozīmīgākās I. Freimanes lingvistiskās idejas, kas saistāmas ar funkcionālo strukturālismu, turpmāk piedāvāts neliels profesores atziņu apkopojums, kura tapšanā izmantotas I. Freimanes monogrāfijas, kā arî vairāki raksti, kas publicēti pēdējā desmitgadē un veltìti gramatikas un semantikas jautājumiem.

Viens no svarīgākajiem terminiem, kas dominē strukturālistu darbos, ir sistēma. Priekšstats par valodu kā funkcionālu sistēmu nosaka gan pašas valodas izpratni, gan arī valodas izpētē izmantotās metodolog̣ijas principus. Pēc strukturālistu domām, sistēma ir priekšnoteikums, kas ļauj izprast jebkuru valodas parādību. Tātad šis termins nodrošina strukturālisma ideju teorētisko, metodolog̣isko un praktisko pamatu. Arī latviešu valodniecībā šis termins tiek plaši izmantots. I. Freimanes darbos termins sistèma dominē kā pamats valodas elementu izpratnei un lingvistiskajai interpretācijai. Izmantojot šo terminu valodas definēšanai, I. Freimane pievienojas strukturālisma pamatkoncepcijai, kurā dominē uzskats, ka valoda ir zìmju sistēma, kas ietver formālā un semantiskā aspekta apvienojumu: „Valoda pastāv kā formā un saturā vienota sistēma. Formas un satura attieksmes valodā parādās izpausmes (formālā) aspekta un satura (semantiskā) aspekta ciešā vienībā. " ${ }^{1}$ (Freimane 1983: 4) Profesore savos pētījumos vairāk pievērsās valodas semantiskajai realizācijai, norādot, ka valodas formālās izpausmes ir atkarīgas no semantikas (Freimane 1983: 4), ka formālās pazīmes ir nosakāmas, tikai ņemot vērā saturu (Freimane 2008: 11), ka semantika ir valodā galvenā un primārā - tā ir dominante (Freimane 2014: 36).

Strukturālistu darbos termins sistēma parasti tiek arī izmantots, lai sīkāk raksturotu valodas sarežğìto dabu, proti, valoda tiek dēvēta par sistēmu, kas sastāv no vairākām apakšsistēmām. „Tēze, ka valoda ir sistēmu sistēma, mūsdienu valodniecībā kḷıvusi par aksiomu. Proti, valoda ir tāda sistēma,

1 Te un turpmāk izmantotajos citātos nav saglabāti oriǵināla izcēlumi, pasvītrojumi, slīpinājumi, atsauces, parinžu norādes, kā arī rindkopu atkāpes. Pēc vajadzības citātu ortogrāfija pielāgota mūsdienu valodas normām. 
kurā var izšķirt dažādas apakšsistēmas (mikrosistēmas) un līmeņus. Šajā aspektā valoda tiek uzskatīta par noteiktu strukturālu apvienojumu. To veido noteiktā veidā organizēti valodas līdzekḷi.“ (Freimane 1993: 25) Pieņemot šādu valodas izpratni, strukturālistu darbos tika attīstīta t. s. valodas līmeņu teorija, ar kuras palīdzību tika definētas, skaidrotas, aprakstītas dažādas valodas apakšsistēmas. Arī I. Freimanes pētniecisko darbību lielā mērā ir ietekmējusi šì teorija. Visos I. Freimanes darbos vērojama līmeņu teorijas klātesamība, tomēr monogrāfijās tā vairāk atklājas kā aksioma, kurai nav dots sīkāks skaidrojums. Plašāka valodas līmeņu teorijas interpretācija ir pieejama I. Freimanes rakstā „Valoda semantiski funkcionālā aspektā“ (sk. Freimane 2014), kurā tiek aplūkots gan terminolog̣ijas jautājums, gan pretrunas līmeņu izpratnē, kā arī izstrādāts savs valodas līmeņu hierarhijas redzējums. I. Freimane piedāvā piecu līmeņu sistēmu: „Pašreiz latviešu valodā atbilstoši dotajai līmeņu definīcijai izsecināmi pieci valodas līmeņi ar tiem piederošiem valodas līdzekḷiem noteiktās savstarpējās attieksmēs. Divi zemākie līmeņi - fonolog̣iski fonētiskais līmenis ar semantiski diferencētājspèjīgu fonēmu centrā un derivācijas līmenis ar derivatīvi motivētu afiksu centrā - attiecināmi uz valodas līdzekḷ̆u tapšanu. [..] Trīs augstākie līmeņi vērsti uz valodas funkcionēšanas sfēru. Gramatiku pārstāv morfolog̣ijas līmenis ar morfēmu centrā un sintakses līmenis ar teikumu centrā. Visaugstākais valodas līmenis ir teksta līmenis ar daudzveidīgu izteikumu sistēmu centrā.“ (Freimane 2014: 49) Domājot par šo līmeņu savstarpējo hierarhiju un mijiedarbi, I. Freimane raksta beigu dạ̦ā piedāvā arī shematisku idejas atspogulojumu ar pievienotiem komentāriem.

Ideja par valodas līmeņiem praktiskā aspektā ir izmantota I. Freimanes monogrāfijā „Valodas kultūra teorētiskā skatīiumā“", kurā analizētie valodas kultūras piemēri ir klasificēti, ņemot par pamatu valodas sistēmas līmeņus. Piemēram, vispirms ir analizētas atkāpes fonēmu lietojumā, tad pievērsta uzmanība vārddarināšanai valodas kultūras aspektā, pēc tam ir aprakstìtas formveidošanas un sintakses nepilnības (sk. Freimane 1993: 141-345). Tāpat tā ir atrodama arī I. Freimanes izstrādātajos „Metodiskajos norādījumos praktiskajiem darbiem valodas kultūras pamatos“ (sk. Freimane 1980) un „Metodiskajos norādījumos studentu patstāvīgajam darbam valodas kultūras pamatos“" (sk. Freimane 1985a), kuros ir aprakstīti nosacījumi, kā studentiem izstrādāt patstāvīgos darbus, rosinot darboties valodas praksē.

Līmenu teorijas ideja ir izmantota arī citos I. Freimanes darbos dažādu teorētisko jautāijumu aprakstīšanā un skaidrošanā. Piemēram, priekšstats par līmeņu hierarhiju izmantots semantikas pētījumos, aprakstot semantiski gramatisko lauku būtību (sk. Freimane 1983: 7-9; Freimane 2008: 22-26). Līmeñu ideja ir izmantota valodas kultūras teorijas izstrādē, proti, valodas kultūras jēdziena izpratnes precizēšanai tiek piedāvāts līmeņu škīirums: pareizuma līmenis un meistarības līmenis. Pareizuma līmenis aptver valodas semiotisko un strukturālo pusi, bet neskar valodas lietojumu konsituācijā, savukārt 
meistarības līmenis paredz valodas līdzekḷu optimālu lietojumu kādā noteiktā runas situācijā (sk. Freimane 1993: 13-16).

Risinot jautājumu par līmeņu teorijas izpratni, I. Freimanes darbos īpaša uzmanība tiek pievērsta galvenajām attieksmēm valodas sistēmā - sintagmatiskajām un paradigmatiskajām attieksmēm. Šis jautājums ir aplūkots gan apcerējumā „Vienkāršs teikums un tā paplašināšana“ (sk. Freimane 1985b: 11, 26), gan monogrāfijā „Valodas kultūra teorētiskā skatīiumā“" (sk. Freimane 1993: 9-10), gan rakstā „Valoda semantiski funkcionālā aspektā““ (sk. Freimane 2014: 44-45). „Sintagmatiskās attieksmes veidojas starp valodas elementiem runas ķēdē; tās ir līdzāspastāvēšanas un secīguma attieksmes. Paradigmatiskās attieksmes veidojas starp valodas elementiem, kuriem ir kaut kas kopējs un kas pēc šìs kopējās pazīmes tiek apvienoti grupās.“ (Freimane 1993: 9) „Valodai funkcionējot, visi līmeņi darbojas vienā laikā un no to vienībām veidojas komunikatīvas valodas vienības. Augstākajiem līmeņiem ir sarežğìtāka uzbūve nekā zemākajiem - tās ir sistēmas, kurās zemāko līmeņu vienības funkcionē kā elementi, kā sastāvdaḷas. Vārdiem ir citas īpašības nekā morfēmām, bet teikumam ir pavisam cita kvalitāte nekā vārdiem, kas to veido - atbilstoši tam piemītošajai predikativitātei tas veic komunikatīvo funkciju. Atsevišķ u vienību vai vienību grupu lineāras kombinācijas kā konkrētas sistēmas veido pāreju uz blaku, kaimiņu līmeni un aktuāli pastāv runas ķēdē. Bezgalīgi atritinot sintagmatisko ķēdi, tajā būs atrodamas visas valodas vienības, visi elementi, kas veido paradigmas un līmen̨us." (Freimane 2014: 48) Sintagmatisko un paradigmatisko attieksmju pretstatu savos darbos postulēja Eiropas strukturālisma pamatlicējs Ferdināns de Sosīrs (Fredinand de Saussure), pēc tam to attīstīja dažādas strukturālisma skolas, arī funkcionālā strukturālisma pārstāvji, un tāpēc šis jautājums funkcionālā strukturālisma atbalstītāju darbos ir sastopams visai bieži.

Vēl viens svarīgs funkcionālā strukturālisma jautājums ir valodas funkcionālais raksturs, jo ikviena valodas līdzekḷa pastāvēěanu valodas sistēmā nosaka tā funkcionālā kapacitāte. Jautājums par valodas funkcionālo dabu ir čehu lingvistiskās skolas pamatpostulāts, un arī I. Freimanes pētījumos tam ir nozīmīga vieta. „Faktiski funkcionālais aspekts ir primārais, jo no tā tiek izdalīts un izsecināts strukturālais - struktūras elementi un attieksmes starp tiem vispārinātā veidā." (Freimane 1993: 25) Tikai funkcionējot valoda atspogulo savu struktūru, kā arī savas potences. Funkcionālā aspekta prioritāte bija l̦oti nozīmīga tajos pētījumos, kas saistīti ar valodas kultūru, jo šai aspektā valodas lietotājs un viņa komunikatīvie mērķi vienmēr ir primāri valodas līdzekḷ̣u atlasē un līdz ar to arī analīzē, tāpēc plašāk šis jautājums ir aplūkots I. Freimanes monogrāfijā „Valodas kultūra teorētiskā skatījumā“ (1993), kā arī iezīmēts I. Freimanes rakstā „Valoda funkcionāli semantiskā aspektā““ (2014). Saistībā ar valodas funkcionālo dabu I. Freimane ir izstrādājusi valodas līdzekḷu funkcionālās aprites modeli. „Visi valodas līdzekḷi ir pakḷauti 
funkcionāli nosacìtām pārmaiņām, tāpēc varam droši teikt, ka valodas līdzekḷı aprite ir funkcionāli nosacìta.“ (Freimane 2017: 28) „Valodas attīstība ir funkcionāli nosacīta. Valodniecībā ir îpaši izdalīti un ievēroti galvenokārt trīs valodas situāciju veidojoši faktori: laiks, vieta un vide.“ (Freimane 2014: 57) Valodas līdzekḷ̂u funkcionālās aprites pamatā ir trīs posmi, kas nodrošina valodas attīstību un īstenojas pamīšus: „Ir trīs galvenās valodas līdzekḷu attīstības fāzes: 1) valodas līdzekḷu tapšana - vārddarināšana, konstrukciju veidošana un aizgūšana; 2) funkcionēšana - valodas līdzekḷu izmantošana un 3) relatīvi pasīvs valodas līdzekḷ krājums, resursi.“ (Freimane 1993: 434) „Ņemot vērā minētās fāzes un valodas līdzekḷ̂u attīstību tajās, būtu likumsakarīgi runāt par valodas līdzekḷu potenciālās nezūdamības likumu, jo valodā nekas pilnīgi nezūd. Neviens nekad nevar garantēt, ka kāds novecojis valodas līdzeklis kādā noteiktā sociālā situācijā, noteiktos nosacịjumos nevarētu atkal atgriezties valodā. Tiesa, bieži vien jau citā statusā. Katram neaktuālam valodas līdzeklim ir potenciāla iespēja aktualizēties. Šo potenču realizācija ir atkarīga no sociālajiem apstākḷiem.“ (Freimane 2014: 59) Jautājums par valodas līdzekḷı funkcionālo apriti galvenokārt ir aplūkots monogrāfijā „Valodas kultūra teorētiskā skatīịumā“ (sk. Freimane 1993: 434-439), kā arī rakstā „Variatīvuma loma valodas līdzekḷ upritē“ (sk. Freimane 2017).

Jebkuru sistēmu veido noteiktas sastāvdaļas, tāpēc strukturālismā īpaša uzman̄iba tiek pievērsta sistēmas elementu izpratnei. I. Freimane, ņemot par pamatu iepriekš pieminēto līmeņu teoriju, valodas sistēmas elementus jeb vienības apraksta šādi: „Katram līmenim ir savas valodas vienības. Viena no tām parasti ir konstruktīva attiecīgajā līmenī un uzskatāma par galveno. Fonolog̣iski fonētiskajā līmenī tā ir fonēma, derivācijas līmenī tas ir vārddarinātājs afikss, morfolog̣ijas līmenī formveidotājs afikss, bet sintakses līmenī tā ir galvenā saziņas vienība - teikums.“ (Freimane 2014: 54) Valodas elementu detalizētā analīzè I. Freimane izmanto strukturēšanas principu, proti, valodas elementi tiek sadalīit sīkāk, izmantojot kādu konkrētu lingvistiski metodolog̊isku paņēmienu. Tāpēc savos zinātniskajos pētījumos profesore izmantoja tādas lingvistiskās metodes kā komponentu analīzes metode (sk. Freimane 1983: 10; Freimane 1984: 9), distributīvās analīzes metode, segmentācijas un substitūcijas metode (sk. Freimane 1993: 4). Valodas elementu analīzē un aprakstīšanā I. Freimane izmantoja arī opozīciju principu, kas bija populārs funkcionālajā strukturālismā. „Opozīcijas izpaužas visās valodas sfērās - gan universālās (semantiskās), gan konkrētās (leksiskās), gan vispārinātās (gramatiskās), un to identificēšana var izvērsties visai sarežğìta. Mēs esam raduši opozīcijas uztvert kā vispārinātas bināras struktūras, taču nav noliedzams, ka to pamatā ir strukturējamas daudzlocekḷ̂u sistēmas. Varētu teikt, ka binārās opozīijas ir sinonīmiski antonīmisku pretstatījumu galējie punkti, bet viens no binārajiem locekḷiem var veidot kompleksu hierarhisku sistēmu, proti, tam var būt pakārtoti citi locekḷi." (Freimane 2008: 19) 
Šis raksts ir tikai neliels ieskats profesores I. Freimanes zinātnisko ideju un zinātnisko meklējumu klāstā, jo, ielūkojoties atkal un atkal viņas darbos, var ieraudzìt jaunus virzienus, jaunas atziņas, jaunas diskusijas, jaunus jautājumus. I. Freimanes zinātniskie darbi, it īpaši to struktūra un noformējums, ir vislabākais apliecinājums viņas piederībai pie latviešu valodnieku strukturālistu paaudzes, jo I. Freimanes pētījumus vienmēr raksturo precīzi izstrādāta sistēma, kurā katram elementam ir sava noteikta vieta un funkcija. Lasītājam šāda sistēma var šksist sarežğīta, bet, ja izdodas izprast un uztvert profesores teorētiskās domas pavedienu, tad sistēmas modelis kḷūst par lielisku palīgu jaunu atziņu atklāsmē un par noderīgu paraugu jaunu pētījumu veikšanā. Savukārt tas nosaka I. Freimanes pētījumu funkcionālumu, jo piedāvātās metodes, izstrādātās shēmas un klasifikācijas rosina uz diskusijām un jauniem meklējumiem valodniecībā.

\section{Literatūra}

Freimane, Inta. 1980. Metodiskie norādïjumi praktiskajiem darbiem valodas kultūras pamatos. Rīga: P. Stučkas Latvijas Valsts universitāte.

Freimane, Inta. 1983. Latviešu valodas skaņu verbi. Rīga: P. Stučkas Latvijas Valsts universitāte.

Freimane, Inta. 1984. Latviešu valodas skaņu verbi: Distributīvs raksturojums. Rīga: P. Stučkas Latvijas Valsts universitāte.

Freimane, Inta. 1985a. Metodiskie norādījumi studentu patstāvīgajam darbam valodas kultūras pamatos. Rīga: P. Stučkas Latvijas Valsts universitāte.

Freimane, Inta. 1985b. Vienkāršs teikums un tā paplašināšana. Rīga: P. Stučkas Latvijas Valsts universitāte.

Freimane, Inta. 1993. Valodas kultūra teorētiskā skatījumā. Rīga: Zvaigzne.

Freimane, Inta. 2008. Trešā persona latviešu verbu sistēmā. Rīga: LU Akadēmiskais apgāds.

Freimane, Inta. 2014. Valoda semantiski funkcionālā aspektā. Kalnača, Andra, Lokmane, Ilze (red.). Valoda: nozìme un forma 5. Opozīcijas sintaksē un semantikā. LU Humanitāro zinātņu fakultātes Latviešu un vispārīgās valodniecības katedras rakstu krājums. Rīga: LU Akadēmiskais apgāds, 33-61.

Freimane, Inta. 2017. Variatīvuma loma valodas līdzekḷu apritē. Kalnača, Andra, Lokmane, Ilze (red.). RES LATVIENSES. IV. Semantika. Sintakse. Valodas kultūra. INTA FREIMANE. SCRIPTUM FESTIVUM. LU Humanitāro zinātņu fakultātes Latvistikas un baltistikas nodaḷas raksti. Rịga: LU Akadēmiskais apgāds, 21-44.

Inta Urbanoviča

Latvijas Universitātes

Humanitāro zinātnu fakultāte

Latviešu un vispārīgās valodniecības katedra

Visvalža iela 4a, LV-1050 Rīga, Latvija

inta.urbanovica@lu.lv 


\section{IZDOŠANAS PRINCIPI}

\section{Izdevuma tematika}

Baltu filoloǵija (BF) publicē pētnieciskus darbus visās baltu valodniecības jomās. Tiek pieņemti arī raksti par citu tematiku, kas var interesēt baltistus. Gaidīti tiek arī pārskata raksti, kas aplūko pētniecības stāvokli noteiktās baltistikas nozarēs, recenzijas, apskati.

\section{Vērtēšana}

Visus rakstus, kas iesniegti publicēšanai, izvērtē anonīmi, un tiem jābūt sagatavotiem tā, lai autora identitāte nav atklāta ne tekstā, ne bibliogrāfiskajās norādēs. Manuskriptu lasa vismaz divi vērtētāji, kas iesaka to pieņemt vai noraidīt, savu lēmumu pamatojot.

\section{Valoda}

BF publicē rakstus latviešu, lietuviešu, angḷu un vācu valodā. Autoriem, kuriem raksta valoda nav dzimtā, jārūpējas, lai viņu manuskripti valodas ziņā būtu sakārtoti jau pirms to iesniegšanas. Pētnieciskajiem rakstiem jāpievieno kopsavilkums ang̣̣u valodā (līdz 250 vārdiem), kas atspogụ̣o satura būtību.

\section{Manuskripta forma}

Autori ir aicināti iesūtīt redakcijai manuskriptu elektroniski Word un Pdf formātā, izmantojot Palemonas šriftu. Titullapā jānorāda raksta nosaukums, autora pilns vārds un akadēmiskā piederība. Manuskripti ir jāraksta ar divu intervālu lielu atstarpi. Pēc iespējas jāvairās no norādēm parindēs. Tabulas, diagrammas un kartes iesūtāmas atsevišksos failos, tās numurējot un nosaucot. Pielikumi pievienojami manuskripta beigās. Atsaucēm uz pielikumiem jābūt tekstā, norādot to vēlamo izvietojumu. Valodu piemēri rakstāmi kursīviem burtiem, nepieciešamais tulkojums vai skaidrojums - vienpēdiṇās (starp apvērstiem komatiem).

\section{Atsauces}

Atsaucēs tekstā minams autora/redaktora uzvārds, izdošanas gads un vajadzīgās lappuses numurs, piemēram, (Rudzìte 1964: 15). Ja ir atsauces uz vairāk nekā vienu tā paša autora publikāciju vienā gadā, aiz gada skaița jāpievieno burti $a, b$ utt. Iekavās jābūt vai nu pilnai atsaucei, vai, ņemot vērā 
kontekstu, tikai gadam un lappusei. Literatūras sarakstā norādāmi tie darbi, uz kuriem autors ir atsaucies tekstā. Literatūras saraksts kārtojams alfabētā pēc autoru/redaktoru uzvārdiem, norādot pilnu bibliogrāfisko informāciju. Piemēri:

\section{Monogrāfija vai rakstu krājums:}

Rudzìte, Marta. 1964. Latviešu dialektoloǵija. Rīga: Latvijas Valsts izdevniecība. Stang, Christian S. 1966. Vergleichende Grammatik der baltischen Sprachen. Oslo, etc.: Universitetsforlaget.

Bergmane, Anna, Aina Blinkena. 1986. Latviešu rakstības attīstība. Latviešu literārās valodas vēstures pētījumi. Rīga: Zinātne.

Ambrazas, Vytautas (ed.). 1997. Lithuanian Grammar. Vilnius: Baltos lankos. Blinkena, Aina (red.). 1997. Savai valodai. Latvijas Zinātṇu Akadēmijas Goda loceklim Rūdolfam Grabim veltīts piemiņas krājums. Rīga: Latvijas Zinātņu Akadēmijas Vēstis.

\section{Sējums sērijā:}

Schmalstieg, William R. 2000. The Historical Morphology of the Baltic Verb. Washington: Institute for the Study of Man. (Journal of Indo-European Studies. Monograph No. 37)

\section{Raksti žurnālos un rakstu krājumos:}

Lagzdiņa, Sarmīte. 1998. Adverbien, Präpositionen oder Halbpräpositionen? Linguistica Baltica 7, 151-166.

Rudzīte, Marta. 1997. Izloksne vietvārdos. Aina Blinkena (red.). Savai valodai. Latvijas Zinātņu Akadēmijas Goda loceklim Rūdolfam Grabim veltīts pieminas krājums. Rịga: Latvijas Zinātṇu Akadēmijas Vēstis, 247-259. 